\title{
Persistent Hypoglycemia Induced by Long-acting Insulin Degludec
}

\author{
Yukino Katakura, Fuminori Tatsumi, Takashi Kusano, Masashi Shimoda, Kenji Kohara, \\ Tomohiko Kimura, Atsushi Obata, Shuhei Nakanishi, Tomoatsu Mune, Kohei Kaku and \\ Hideaki Kaneto
}

\begin{abstract}
:
A 58-year-old Japanese man was brought to the emergency room due to disturbance of consciousness. He regained consciousness on the day of admission and started taking hospital meals, but he needed intravenous glucose administration for eight days. The total amount of glucose administration was 4,464 g. It took over three weeks for exogenous insulin to be almost undetectable. While degludec binds to albumin and exerts glucose-lowering effects for a long time, the above-mentioned period of three weeks was consistent with the half-life of albumin. Hypoglycemia induced by massive dose of insulin degludec is persistent and prominent.
\end{abstract}

Key words: severe hypoglycemia, insulin therapy, insulin degludec, a pitfall, diabetes care

(Intern Med Advance Publication)

(DOI: 10.2169/internalmedicine.7915-21)

\section{Introduction}

Hypoglycemia is induced by various causes, including overuse of some anti-diabetic drugs or certain disorders, such as insulinoma, insulin autoimmune syndrome and adrenal insufficiency (1-3). It is well known that severe and/or repeated hypoglycemia leads to various clinical problems, such as acute coronary syndrome, fundus hemorrhaging and unconscious hypoglycemia $(4,5)$. It is also well known that hypoglycemia facilitates the development of dementia, especially in elderly subjects. Therefore, it is very important to prevent hypoglycemia as well as to obtain good glycemic control in subjects with diabetes mellitus. Insulin degludec is a long-acting insulin preparation used very often to obtain good glycemic control in subjects with type 1 and type 2 diabetes mellitus. It is well known that insulin degludec exerts glucose-lowing effects for a longer period of time than other insulin preparations (6-14).

We herein report a patient with prominent and persistent hypoglycemia induced by the administration of a massive dose of degludec.

\section{Case Report}

A 58-year-old Japanese man was brought to the emergency room in our institution due to disturbance of consciousness. This individual had mental developmental delay and had been in a facility for patients with mental retardation. He had had severe acute pancreatitis in 2013, after which we started insulin therapy for pancreatic diabetes with long-acting insulin degludec and rapid-acting insulin glulisine. When we started insulin degludec, his fasting serum C-peptide immunoreactivity (CPR) had been $0.6 \mathrm{ng} /$ $\mathrm{mL}$, and his CPR index had been 0.52, indicating that endogenous insulin secretion was markedly limited in this subject. Since he repeatedly experienced hypoglycemia, we gradually decreased the insulin dose. In 2020, we stopped insulin degludec, and he took only 4 units/day of insulin glulisine ( 2 units just before breakfast and supper). Endogenous insulin secretion was low but not depleted, with the following findings: fasting serum C-peptide, $0.8 \mathrm{ng} / \mathrm{mL}$; Cpeptide index, $0.65 ; \Delta \mathrm{CPR}$ in glucagon load test, $0.8 \mathrm{ng} / \mathrm{mL}$. We considered him not to need larger amounts of insulin because his endogenous insulin secretion was not depleted. He 
Table 1. Laboratory Data in This Subject.

\begin{tabular}{|c|c|c|c|c|c|}
\hline \multicolumn{2}{|c|}{ Peripheral blood } & \multicolumn{2}{|c|}{ Diabetes and endocrine markers } & \multicolumn{2}{|c|}{ Electrolytes } \\
\hline $\mathrm{RBC}$ & $421 \times 10^{4} / \mu \mathrm{L}$ & Plasma glucose & $25 \mathrm{mg} / \mathrm{dL}$ & Sodium & $148 \mathrm{mEq} / \mathrm{L}$ \\
\hline Hemoglobin & $13.5 \mathrm{~g} / \mathrm{dL}$ & C-peptide & $0.1 \mathrm{ng} / \mathrm{mL}$ & Potassium & $2.9 \mathrm{mEq} / \mathrm{L}$ \\
\hline WBC & $6,970 / \mu \mathrm{L}$ & Insulin & $<0.1 \mu \mathrm{U} / \mathrm{mL}$ & Chloride & $106 \mathrm{mEq} / \mathrm{L}$ \\
\hline neutrophils & $79.3 \%$ & Total insulin & $1,856.1 \mu \mathrm{U} / \mathrm{mL}$ & Calcium & $9.5 \mathrm{mg} / \mathrm{dL}$ \\
\hline Lymphocytes & $16.6 \%$ & $\mathrm{HbA} 1 \mathrm{c}$ & $8.2 \%$ & Phosphorous & $3.2 \mathrm{mg} / \mathrm{dL}$ \\
\hline Platelet & $23.3 \times 10^{4} / \mu \mathrm{L}$ & Glycoalbumin & $25.7 \%$ & Magnesium & $1.9 \mathrm{mg} / \mathrm{dL}$ \\
\hline \multicolumn{2}{|c|}{ Blood biochemistry } & ACTH & $65.2 \mathrm{pg} / \mathrm{mL}$ & \multicolumn{2}{|c|}{ Lipid markers } \\
\hline Total protein & $7.6 \mathrm{~g} / \mathrm{dL}$ & Cortisol & $39.1 \mu \mathrm{g} / \mathrm{dL}$ & LDL-cholesterol & $86 \mathrm{mg} / \mathrm{dL}$ \\
\hline Albumin & $4.6 \mathrm{~g} / \mathrm{dL}$ & $\mathrm{GH}$ & $7.81 \mathrm{ng} / \mathrm{mL}$ & HDL-cholesterol & $57 \mathrm{mg} / \mathrm{dL}$ \\
\hline Total bilirubin & $0.3 \mathrm{mg} / \mathrm{dL}$ & IGF-1 & $212 \mathrm{ng} / \mathrm{mL}$ & Total cholesterol & $180 \mathrm{mg} / \mathrm{dL}$ \\
\hline AST & $54 \mathrm{U} / \mathrm{L}$ & Adrenaline & $424 \mathrm{pg} / \mathrm{mL}$ & Triglyceride & $70 \mathrm{mg} / \mathrm{dL}$ \\
\hline ALT & $50 \mathrm{U} / \mathrm{L}$ & Noradrenaline & $667 \mathrm{pg} / \mathrm{mL}$ & Auto-antibodies & \\
\hline$\gamma$-GTP & $17 \mathrm{U} / \mathrm{L}$ & Dopamine & $13 \mathrm{pg} / \mathrm{mL}$ & Anti-GAD Ab & $<5.0$ \\
\hline LDH & $215 \mathrm{U} / \mathrm{L}$ & Glucagon & $7.8 \mathrm{pg} / \mathrm{mL}$ & Anti-insulin $\mathrm{Ab}$ & \\
\hline ALP & $96 \mathrm{U} / \mathrm{L}$ & TSH & $2.16 \mu \mathrm{U} / \mathrm{mL}$ & Concentration & $189.8 \mathrm{nU} / \mathrm{mL}$ \\
\hline Creatinine & $0.79 \mathrm{mg} / \mathrm{dL}$ & FT3 & $2.81 \mathrm{pg} / \mathrm{mL}$ & Binding rate & $0.7 \%$ \\
\hline BUN & $17 \mathrm{mg} / \mathrm{dL}$ & FT4 & $0.78 \mathrm{ng} / \mathrm{mL}$ & Anti-IR Ab & negative \\
\hline Amylase & $113 \mathrm{U} / \mathrm{L}$ & & & & \\
\hline CRP & $0.07 \mathrm{mg} / \mathrm{dL}$ & & & & \\
\hline
\end{tabular}

RBC: red blood cells, WBC: white blood cells, AST: aspartate aminotransferase, ALT: alanine aminotransferase, $\gamma$-GTP: $\gamma$-glutamyl transpeptidase, LDH: lactate dehydrogenase, ALP: alkaline phosphatase, BUN: blood urea nitrogen, CPR: C-reactive protein, ACTH: adrenocorticotropic hormone, GH: growth hormone, IGF-1: insulin-like growth hormone, TSH: thyroid stimulating hormone, FT3: free triiodothyronine, FT4: free thyroxine, ACTH: adrenocorticotropic hormone, GAD: glutamic acid decarboxylase, Ab: antibody, IR: insulin receptor

also took $8 \mathrm{mg}$ of candesartan and $5 \mathrm{mg}$ of amlodipine for hypertension and $2.5 \mathrm{mg}$ of rosuvastatin for dyslipidemia.

On admission, his height and body weight were $155.5 \mathrm{~cm}$ and $53.2 \mathrm{~kg}$, respectively. His blood pressure, heart rate and body temperature were $102 / 66 \mathrm{mmHg}, 64 / \mathrm{min}$ and $36.6{ }^{\circ} \mathrm{C}$, respectively. There were no abnormalities on chest X-ray or an electrocardiogram. Table 1 shows the laboratory data on admission. His plasma glucose level was as low as $25 \mathrm{mg}$ / dL. C-peptide and insulin levels were very low at $0.1 \mathrm{ng} / \mathrm{mL}$ and $<0.1 \mu \mathrm{U} / \mathrm{mL}$, respectively. The C-peptide level was markedly low. We suspected that such a marked reduction in C-peptide and insulin levels might have been due to massive dose administration of insulin preparation. Hemoglobin A1c was $8.2 \%$, and glycoalbumin was $25.7 \%$. On a glucagon load test, the $\Delta$ C-peptide was as low as $0.5 \mathrm{ng} / \mathrm{mL}$. Various counter-regulatory hormone levels were increased: ACTH, $65.2 \mathrm{pg} / \mathrm{mL}$ (reference range: 7.2-63.3 pg/mL); cortisol, 39.1 $\mu \mathrm{g} / \mathrm{dL}$ (7.07-19.6 $\mu \mathrm{g} / \mathrm{dL})$; growth hormone, $7.81 \mathrm{ng} / \mathrm{mL}(0-$ $2.47 \mathrm{ng} / \mathrm{mL})$; adrenaline, $424 \mathrm{pg} / \mathrm{mL}(0-100 \mathrm{pg} / \mathrm{mL})$; and noradrenaline, $667 \mathrm{pg} / \mathrm{mL}(100-450 \mathrm{pg} / \mathrm{mL})$. However, the glucagon level was low $(7.8 \mathrm{pg} / \mathrm{mL})(5.4-55.0 \mathrm{pg} / \mathrm{mL})$ despite his severe hypoglycemia. Regarding electrolytes, moderate hypokalemia was observed (potassium, $2.9 \mathrm{mmol} / \mathrm{L}$ ). Mild liver dysfunction was observed, but the renal function was within the normal range (AST, $54 \mathrm{U} / \mathrm{L}$; ALT $50 \mathrm{U} / \mathrm{L}$; creatinine, $0.79 \mathrm{mg} / \mathrm{dL}$; blood urea nitrogen, $17 \mathrm{mg} / \mathrm{dL}$ ). In addition, inflammation markers were within normal range.

Abdominal contrast computed tomography (CT) revealed pancreatic tail atrophy, probably due to his history of severe acute pancreatitis, but no malignant findings were noted, including insulinoma. Hypoglycemia is often induced by the overuse of several anti-diabetic drugs, but this subject used only 4 units/day of insulin glulisine, and he did not use any other anti-diabetic drugs. Since his insulin level was not high and anti-insulin antibody was negative, we excluded the possibility of insulinoma or insulin autoimmune syndrome. In addition, since his cortisol level was not low, we excluded the possibility of adrenal insufficiency. Hypoglycemia can be induced by drinking too much alcohol without enough food intake, but this subject had stopped drinking alcohol after severe acute pancreatitis in 2013. To examine the cause of hypoglycemia, we measured the total insulin level (endogenous plus exogenous insulin level). Surprisingly, the total insulin level was as high as $1,856.1 \mu \mathrm{U} / \mathrm{mL}$.

$\mathrm{He}$ regained consciousness on the day of admission and started taking hospital meals $(1,600 \mathrm{kcal} / \mathrm{day}$, carbohydrate $260 \mathrm{~g} /$ day). Nonetheless, he needed intravenous glucose administration for as long as eight days. The total amount of glucose administration was as large as 4,464 g. As shown in Table 2, even on day 8, the estimated exogenous insulin level (total insulin level - endogenous insulin level) was 37.3 $\mu \mathrm{U} / \mathrm{mL}$. This estimated exogenous insulin level on day 12 and 16 was $18.6 \mu \mathrm{U} / \mathrm{mL}$ and $9.4 \mu \mathrm{U} / \mathrm{mL}$. It took over three weeks for exogenous insulin to be almost undetectable. The endogenous insulin level gradually increased with the decrease in the estimated exogenous insulin level (Table 2). While degludec binds to albumin and exerts glucoselowering effects for a long time, the above-mentioned period 
Table 2. Time Course of Estimated Exogenous Insulin Level (total Insulin Level - Endogenous Insulin Level).

\begin{tabular}{lcccccc}
\hline & Day 1 & Day 8 & Day 12 & Day 16 & Day 20 & Day 27 \\
\hline Blood glucose $(\mathrm{mg} / \mathrm{mL})$ & 25 & 106 & 130 & 147 & 155 & 168 \\
Total insulin $(\mu \mathrm{U} / \mathrm{mL})$ & $1,856.1$ & 38.7 & 20.3 & 11.8 & 6.4 & 4.2 \\
Endogenous insulin $(\mu \mathrm{U} / \mathrm{mL})$ & $<1.0$ & 1.4 & 1.7 & 2.4 & 2.0 & 3.9 \\
Estimated exogenous insulin $(\mu \mathrm{U} / \mathrm{mL})$ & $1,856.1$ & 37.3 & 18.6 & 9.4 & 4.4 & 0.3 \\
\hline
\end{tabular}

of three weeks was consistent with the half-life of albumin. We thus considered the possibility that the overuse of degludec was the cause of hypoglycemia. By 3 days after admission, we began to considered the possibility that this subject suffered from hypoglycemia due to degludec, as his insulin level was as high as $1,856 \mu \mathrm{IU} / \mathrm{mL}$ and the hypoglycemia was prolonged, but we failed to confirm such a possibility. We asked the facility staff and his family to check the patient's room, and they found insulin degludec, which we had stopped prescribing nearly one year earlier. We finally diagnosed this subject with prominent and persistent hypoglycemia induced by the administration of a massive dose of insulin degludec. Needless to say, we explained to the facility staff that a fixed dose of insulin should be injected every day and that the insulin injection should be watched over by the facility staff. However, we cannot exclude the possibility that this subject self-adjusted insulin dose when the facility staff did not watch over insulin injection. In addition, we strictly instructed the facility staff on the necessity of discarding residual insulin preparations and confirmed this point verbally. However, we believe that this was not performed thoroughly, with insulin degludec being actually left in the patient's room. As he did not appear to have been attempting suicide, why the patient injected such a massive dose of insulin remains unclear. However, since he had mental developmental delay, it was likely that his cognitive function was impaired and this injection was performed in error.

\section{Discussion}

In the present report, we described a subject who had prominent and persistent hypoglycemia induced by the administration of a massive dose of long-acting insulin degludec. Although he regained consciousness on the day of admission and started taking hospital meals, he needed intravenous glucose administration for eight days. The total amount of glucose administration was 4,464 g. Furthermore, it took over three weeks for exogenous insulin to be almost undetectable.

In the present subject, endogenous insulin was measured with an insulin measurement kit FUJIREBIO Inc. (Tokyo, Japan). This measurement principle was based on the onestep sandwich method using ALP-labeled anti-insulin monoclonal antibody. In the cross-reaction test of this method, there was no cross-reactivity with insulin degludec. However, the total insulin was measured with a chemiluminescence immunoassay using an insulin measurement kit (Sie- mens Healthineers Inc. (Tokyo, Japan). This measurement principle was also based on the one-step sandwich method using acrydinium ester-labeled anti-insulin monoclonal antibody. In the cross-reaction test of this method, we noted cross-reactivity with various kinds of insulin preparations.

It is well known that persistent hypoglycemia leads to various clinical problems, such as acute coronary syndrome, fundus hemorrhaging and unconscious hypoglycemia $(4,5)$. It is also well known that hypoglycemia facilitates the development of dementia, especially in elderly subjects. Therefore, it is very important to prevent hypoglycemia as well as to obtain good glycemic control in subjects with diabetes mellitus. It is noted here that since insulin degludec forms a multi-hexamer under the skin and exerts glucose-lowering effects for a long time through its binding to albumin in the circulating blood flow, hypoglycemia induced by degludec is considered to be prominent and persistent, as observed in this subject. Given a report showing the time course of the serum insulin level after the injection of 300 doses of degludec (15), we assume that this subject injected quite a large amount of insulin degludec, but it would be very difficult to estimate the injected dose of degludec based on the serum insulin level, as there is marked variation among patients in endogenous insulin secretory capacity and insulin resistance.

In this subject, the glucagon level was as low as $7.8 \mathrm{pg} /$ $\mathrm{mL}$ (reference range: $5.4-55.0 \mathrm{pg} / \mathrm{mL}$ ) despite his severe hypoglycemia (blood glucose: $25 \mathrm{mg} / \mathrm{dL}$ ), although other counter-regulatory hormone levels were increased. Since the response of serum glucagon levels was reportedly poor under hypoglycemic conditions in subjects with chronic pancreatitis (16), the glucagon response may have worsened due to his history of severe acute pancreatitis. In addition to the above-mentioned characteristics of insulin degludec, we suspect that such a worsened glucagon response was also involved in the prominent and persistent hypoglycemia in this subject.

We feel that the present case report highlights a variety of important messages. First, hypoglycemia triggered by insulin degludec is quite persistent and prominent. Second, we should be careful of triggering hypoglycemia when we use insulin degludec in subjects with a limited glucagon response, such as those with a history of severe pancreatitis. Third, we should give strict instructions concerning the need to discard residual insulin preparations and confirm such actions thoroughly. Fourth, we should bear in mind the possibility of massive insulin injection in subjects experiencing 
severe hypoglycemia with marked hyperinsulinemia and lowered C-peptide levels. Finally, this case report underscores the importance of choosing anti-diabetic drugs, including insulin preparations, especially in subjects with a poor condition, in clinical practice. The choice to administer long-acting insulin degludec per se did not appear to have been appropriate for this subject, because severe hypoglycemia in this subject was likely induced by the following reasons: possible poor response of glucagon secretion, presumably due to severe pancreatitis; an insufficient evaluation of the potential decline in his cognitive function, and the insulin preparations being managed by the facility staff rather than his own family.

When we fail to detect the cause of hypoglycemia, we should check the total insulin level in clinical practice. We should also bear in mind that hypoglycemia induced by a massive dose of insulin degludec is persistent and prominent, and we should take care of such subjects very carefully for a long period of time.

The authors state that they have no Conflict of Interest (COI).

Contribution statement: Y.K., F.T., T.K., H.K. researched data and/or wrote the manuscript. M.S., K.K., T.K., A.O., S.N., T.M., K.K. contributed to the discussion. All authors have read and approved the manuscript.

Funding: There was no funding for this work.

\section{References}

1. Frier BM. Hypoglycaemia in diabetes mellitus: epidemiology and clinical implications. Nat Rev Endocrinol 10: 711-722, 2014.

2. Shah P, Rahman SA, Demirbilek H, Güemes M, Hussain K. Hyperinsuliaemic hypoglycaemic in children and adults. Lancet Diabetes Endocrinol 5: 729-742, 2017.

3. International Hypoglycaemia Study Group. Hypoglycaemia, cardiovascular disease, and mortality in diabetes: epidemiology, pathogenesis, and management. Lancet Diabetes Endocrinol 7: 385-396, 2019.

4. Ghosal S, Sinha B. Hypoglycaemia and CV risk: Perceptions and reality. Diabetes Metab Syndr 9: 364-365, 2015.

5. Guemes M, Rahman SA, Kapoor RR, et al. Hyperinsulinemic hypoglycemia in children and adolescents: Recent advances in understanding of pathophysiology and management. Rev Endocr Metab Disord 21: 577-597, 2020.
6. Birkeland KI, Home PD, Wendisch U, et al. Insulin degludec in type 1 diabetes: a randomized controlled trial of a new-generation ultra-long-acting insulin compared with insulin glargine. Diabetes Care 34: 661-665, 2011.

7. Heise T, Tack CJ, Cuddihy R, et al. A new-generation ultra-longacting basal insulin with a bolus boost compared with insulin glargine in insulin-naive people with type 2 diabetes: a randomized, controlled trial. Diabetes Care 34: 669-674, 2011.

8. Zinman B, Fulcher G, Rao PV, et al. Insulin degludec, an ultralong-acting basal insulin, once a day or three times a week versus insulin glargine once a day in patients with type 2 diabetes: a 16week, randomised, open-label, phase 2 trial. Lancet 377: 924-931, 2011.

9. Tahrani AA, Bailey CJ, Barnett AH. Insulin degludec: a new ultralongacting insulin. Lancet 379: 1465-1467, 2012.

10. Heller S, Buse J, Fisher M, et al. BEGIN Basal-Bolus Type 1 Trial Investigators. Insulin degludec, an ultra-longacting basal insulin, versus insulin glargine in basal-bolus treatment with mealtime insulin aspart in type 1 diabetes (BEGIN Basal-Bolus Type 1): a phase 3, randomised, open-label, treat-to-target noninferiority trial. Lancet 379: 1489-1497, 2012.

11. Garber AJ, King AB, Del Prato S, et al. NN1250-3582 (BEGIN BB T2D) Trial Investigators. Insulin degludec, an ultra-longacting basal insulin, versus insulin glargine in basal-bolus treatment with mealtime insulin aspart in type 2 diabetes (BEGIN Basal-Bolus Type 2): a phase 3, randomised, open-label, treat-to-target noninferiority trial. Lancet 379: 1498-1507, 2012.

12. Demir T, Turan S, Unluhizarci $K$, Topaloglu $O$, Tukek $T$, Gogas Yavuz D. Use of insulin degludec/insulin aspart in the management of diabetes mellitus: expert panel recommendations on appropriate practice patterns. Front Endocrinol 12: 616514, 2021.

13. Bolli GB, Cheng A, Charbonnel B, et al. Glycaemic control and hypoglycaemia risk with insulin glargine $300 \mathrm{U} / \mathrm{mL}$ and insulin degludec $100 \mathrm{U} / \mathrm{mL}$ in older participants in the BRIGHT trial. Diabetes Obes Metab 2021.

14. Alexopoulos AS, Andersen A, Donatsky AM, Gowda A, Buse JB. Duration of type 2 diabetes does not appear to moderate hypoglycaemia rate with insulin degludec versus insulin glargine U100. Diabetes Obes Metab 2021.

15. Uchida J, Oikawa Y, Katsuki T, Takeda H, Shimada A, Kawai T. Insulin degluded overdose may lead to long-lasting hypoglycaemia through its markedly prolonged half-life. Diabet. Med 35: 277280, 2018.

16. Linde J, Nilsson LH, Barany FR. Diabetes and hypoglycemia in chronic pancreatitis. Scand J Gastroenterol 12: 369-373, 1977.

The Internal Medicine is an Open Access journal distributed under the Creative Commons Attribution-NonCommercial-NoDerivatives 4.0 International License. To view the details of this license, please visit (https://creativecommons.org/licenses/ by-nc-nd/4.0/).

\section{(C) The Japanese Society of Internal Medicine Intern Med Advance Publication}

